\title{
Analysis and Practice of the Cultivation Methods of Students' Innovative Ability Based on Industry- University-Research Cooperation
}

\author{
Shuqin Li* 1 st \\ Computer Academy \\ Beijing Information Science \& Technology University \\ Beijing, China \\ Lishuqin_de@126.com
}

\author{
Kun Meng 2nd, Meng Ding 3th \\ Computer Academy \\ Beijing Information Science \& Technology University \\ Beijing, China
}

\begin{abstract}
The most popular technologies such as artificial intelligence and big data are inseparable from the support of computers. Those who are proficient in the working principle of computer systems and innovative in using computer technology to solve real problems in production and life have become the shortages required in the current stage of social development. By analyzing the law of students' cognitive development, we plan to implement a program that can gradually cultivate students' innovative ability, and design targeted practical cases and assessment methods for each level of cognition. The results of teaching practice in the past three years show that this process is not only conducive to systematically cultivating students computational thinking ability, but also better able to train students' comprehensive ability to solve complex engineering problems. In addition, the process also demonstrates the level of teaching and research to instructors and the output of cooperative enterprise $R \& D$ results will be accelerated.
\end{abstract}

Keywords-Industry-university-Research

Cooperation; innovation ability training; practical teaching system; computer game

\section{INTRODUCTION}

Since 2018, the large-scale talent introduction plan launched across the country has fully demonstrated the huge demand for talents in economic and social development. With the continuous improvement of the level of informatization, intelligent (smart) has become a concentrated expression of the level of social development, and the demand for talents with high-quality information technology capabilities is increasing day by day. As an important part of social innovation ability, especially the original innovation ability, colleges and universities are further strengthening the status of talent cultivation and scientific research, and the improvement of social service ability is an important measure to reflect the functions of colleges and universities. Achieving a talented education as the core, giving full play to the advantages of talents, improving the ability of scientific research and social services, research and social service scenarios, and feeding education, has become more and more important.

In fact, the report of the 19th National Congress of the Communist Party of China pointed out that "we must deepen the reform of the science and technology system, establish a

This work is Supported by the special bidding project of teaching \& education reform BISTU (2017JGZB08), the general project of teaching \& education reform BISTU(2017JGYB31;2017JGYB34). technological innovation system that takes enterprises as the mainstay, market-oriented, and deep integration of production, education and research, strengthens support for SMEs' innovation, and promotes the transformation of scientific and technological achievements. Advocate innovation cultures, strengthen the creation, protection and application of intellectual property rights, and cultivate a large number of strategic scientific and technological talents, leading scientific and technological talents, young scientific and technological talents and high-level innovation teams with international standards. $^{.[1]}$. Therefore, it is easily to see that the role and function of universities in scientific and technological innovation and social services have been further defined. Enterprises are still the mainstay of technological innovation, and the integration of Industry-university-Research into service technology innovation is the road to innovation that must be adhered to. Talent is the guarantee for continuous innovation. However, there are still many shortcomings in the current industry-university-research cooperation, especially in the industry-university cooperation to support personnel training. A number of articles have summarized the shortcomings of the current stage. ${ }^{[2-4]}$ :

1) Insufficient understanding of the deep integration of production, education and research. Most colleges simply believe that school-enterprise cooperation is only to introduce the company's technical equipment resources, or to increase the off-campus training internship units. Enterprises often sell their own products in the face of the school, and do not know the value of the university's human resources and scientific research capabilities for the development of the enterprise. They are not standing at the new height of education reform, and understand the deep value of the deep integration of Industry-university-Research to the cultivation of talent innovation ability and the development strategy of the country.

2) The connotation of Industry-university-Research is insufficient, and the depth of collaborative education is not enough. At present, school-enterprise companies tend to pay too much attention to form, emphasizing the number of equipment, venue scale, practical courses, etc., while adjusting the substantive construction not enough content such as student training programs, teaching materials construction, employment quality, project development, technical services, 
and team training and the company's demand for talents is not deeply integrated into the school's development plan.

3) The ties between schools and enterprises that are interdependent and achieve a win-win situation have not yet been formed, and there are not many landmark achievements. The school pays attention to the use of enterprise resources to cultivate applied talents. The enterprise pays attention to the ability of colleges and universities to help enterprises solve key problems and the dividends brought by cooperation.

4) The long-term mechanism and management mechanism of school-enterprise cooperation has not been fully established. At present, schools and enterprises are often "one-off" for the funding of school-enterprise cooperation projects, lacking postmaintenance, renewal, and upgrading.

5) The teaching evaluation mechanism is absent. The current teaching evaluation mechanism cannot meet the needs of practical teaching reform, and cannot strengthen the enthusiasm of encouraging practice teaching links and encouraging reform and innovation in practical teaching links. On the contrary, there is a tendency to restrict. In particular, it is still necessary to explore in depth the evaluation of the results of the students' practical courses and the conversion of the workload of teachers' practical teaching.

This paper focuses on the problems encountered by local application-oriented undergraduate colleges in the integration of Industry-university-Research. Combining with the example of our school, starting from the cultivation of high-quality informatization talents needed for social development, starting from the cultivation of computational thinking, considering student cognition on the basis of the law of horizontal development, combined with the needs of innovative production, education and research combined with the construction of campus bases, this paper explored the progressive practical teaching system and talent training mode based on the extensive practice resources of campus bases, and obtained some practical practices and result.

The rest of the paper will be developed according to the following structure. The second part discusses the construction plan of Industry-university-Research Campus Base in the Beijing Information Science and Technology University Technology, and gives analysis and solutions to the problems encountered. The third part gives a detailed practical teaching plan based on the cultivation of students' Computational thinking ability, and gives the realization method relying on campus base. The last part of the paper comprehensively analyzes the practical results in the past three years and explores the future development model.

\section{INDUSTRY- UNIVERSITY -RESEARCH CAMPUS BASE CONSTRUCTION}

\section{A. Relying on the research team, build an innovative industry-university-research joint campus}

The industry-university-research model mainly introduces the concept of scientific research into the cultivation of talents. The integration of scientific research concepts can not only promote the advancement of research work in enterprises and schools, but also inspire and guide students to focus on scientific research and be brave in scientific research.

With the deepening of the level of cooperation between China's domestic research and research and the diversification of cooperation paths, the model of innovative talent cultivation through industry-university-research cooperation has also shown diversified characteristics. According to the different main body of the industry-university-research cooperation, the model of domestic production, research and research cooperation to cultivate innovative talents is mainly divided into typical models relying on the college model, relying on the project model, joint training talent model, regional cooperation mode, and custom mode ${ }^{[5]}$.Local applied undergraduate colleges and universities account for the majority of colleges and universities in China. In the past, they mainly focused on teaching. They have strong teaching and organizational skills, and can pass knowledge to students according to certain training objectives. Although some of them have become teaching and research universities, Compared with scientific research universities such as 985 and 211, the research ability is weak, and there is no engineering education environment that is synchronized with the development of industry technology.

However, there are many research teams active in these universities, including research centers, teacher and student teams, and discipline teams. The scientific research center is a group of scientific research personnel who are responsible for the research and development of science and technology and whose research interests, research goals and working methods are mutually responsible; the teacher and student team is composed of the tutor and its graduate students. It is oriented to the needs of talent cultivation, has a clear academic direction and research topics, and focuses on cultivating research methods and research capabilities of graduate students; the subject team is a group consisting of academic leaders and a certain number of teachers according to the direction of the discipline, such as Teaching and research room, experimental center, network center, etc. The university research team is the leader and main force of scientific research in the school. It is a solid guarantee for the long-term development of higher education institutions and the steady improvement of teaching quality. It is also an important guarantee for colleges and universities to cultivate innovative talents. On the one hand, the research team has the ability to use professional advantages to solve some problems in enterprise product development and technology research and development, to provide technical and intellectual support for the long-term development of the enterprise, and to combine the school research projects with the production and operation of the enterprise to promote scientific research in universities. This is conducive to the smooth flow of school-enterprise cooperation channels and the establishment of a long-term, stable and mutually beneficial cooperation mechanism. On the other hand, the research team members have rich experience in education and teaching, can bring the latest technology to teaching, and promote the effective implementation of teaching reform programs.

Therefore, the project cooperation as the link, the training of practical talents as the goal, it is relying on the university 
research team, to build an innovative industry-universityresearch joint campus base model as shown in Fig. 1.

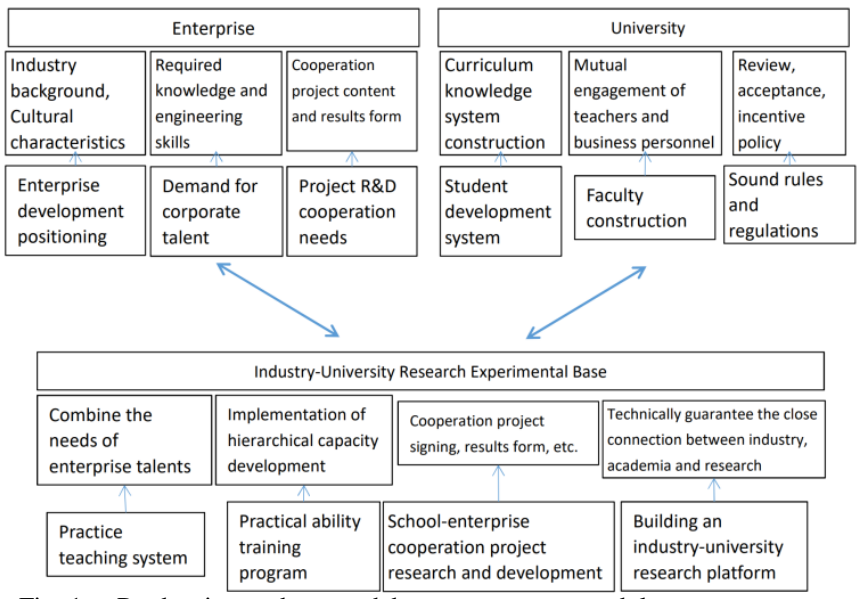

Fig. 1. Production and research base component model

\section{B. Main duties of the Industry-University-Research campus base}

The deep integration of industry, university and research is an important measure for the implementation of educational reform programs in higher education institutions. It is the innovation of educational concepts and aims to cultivate highlevel special talents that meet the needs of enterprises and have scientific research competitiveness. All parties in the IndustryUniversity -Research campus base should raise their awareness and take responsibility.

In terms of enterprises, we must have a clear positioning for our own development, aim at long-term development, and fulfill the main responsibilities of school-enterprise cooperation. We should change the traditional concept, turn the demand for talents into the cultivation of talents, actively participate in the talent cultivation process of colleges and universities in the strategic planning of talents, and strive to develop the school into the talent reserve center of the enterprise. Enterprises have the environmental advantages of production practice, and should provide students with the venues, experimental equipment, raw materials and project funds needed for scientific research as much as possible, and create basic conditions for students to conduct experimental research. Fully aware of the value brought by the establishment of the industry-university-research community, such as the joint university teacher application project, relying on college teachers to solve problems encountered in product development.

In terms of schools, in order to cultivate innovative practical talents, it is necessary to carry out innovative reforms in terms of student training system formulation, teacher team building, and improvement of innovation management mechanisms, and deepen the cooperative relationship with enterprises in order to achieve a "win-win" situation for schools and enterprises.

1) Construct a new model for the cultivation of innovative talents. At present, the applied talent training program system formulated by the school is mainly divided into three parts: professional courses, practical courses (experiment, internship, course design and graduation design) and innovative entrepreneurship (extracurricular activities, science and technology competition). It mainly cultivates students' professional knowledge system, practical ability and humanistic quality, and innovation consciousness. In the current teaching plan, although the teaching time of the practice link has been greatly improved, the practical time available for student practice or hands-on is still insufficient, and the experimental content is still based on the basic and professional courses. It is far from the engineering practice ability required by the company. Schools must constantly explore new models for the cultivation of innovative talents, establish and improve students in accordance with their aptitude and diversified talent management mechanisms. Student-centered, training programs should be linked to industrial needs, professional standards and production practices, and the cultivation of innovative capabilities should be placed in an important position to achieve the unity of talent cultivation and social needs.

2) Construction of the teaching staff. Teachers are the first core element of colleges and universities. The construction of the joint campus of production and education requires teachers to have the professional technical ability of "standing the platform and doing scientific research", and also requires the ability to transform and serve the localities. Schools should encourage teachers to participate in new technology training, joint ventures to conduct applied research, continuously improve teachers' professional knowledge in various ways, enhance teachers' scientific research capabilities, and improve the overall quality of teachers. Support teachers and researchers to link research results with the market and society to carry out innovative and entrepreneurial activities. At the same time, hire industry experts and senior engineers to teach professional courses, optimize the structure of the teaching staff, build a teaching team with complementary advantages, and improve teachers' competence in practical teaching.

3) Establish a sound policy guarantee system. Colleges and universities need to introduce policies to encourage teachers and students to participate in innovative practices and participate in the construction of production, education and research bases. It will open up practical guidance and traditional classroom teaching workload as well as the substitution of practical results and scientific research results, and provide reasonable practice credits recognition scheme for participating students. As a student's supervisory body, the school should formulate corresponding management systems and implementation methods in various aspects, and establish corresponding functional departments to conduct supervision and assessment at all levels in order to maintain the benign and sustainable development of the Industry- University -Research campus base. Before the establishment of the IndustryUniversity -Research campus base, the selection of the schoolenterprise cooperation profession is reviewed. Does the experimental base have the ability to guide students' innovative practice, the number of internships that can be provided, and whether the implementation plan is feasible; whether teachers and students really completed the guidance of students' practical ability. Each graduate should evaluate whether the Industry-University-Research cooperation model has 
effectively improved students' practical ability, especially the third-party evaluation of other industries or enterprises.

Industry-University-Research campus bases, it is necessary to recognize that practical teaching is a key link in the process of training innovative talents and a weak point in higher education. The education of Industry-UniversityResearch campus base is to create a new form of education that combines the school education with the main knowledge of the classroom and the production and scientific research practices that directly acquire the practical experience.

1) The establishment of a practical teaching system. Schools and enterprises jointly develop scientific and standardized practical teaching plans, improve teaching methods, and build practical courses that are close to reality, attract students' practical cases, reflect the assessment methods of ability training, control the practice process, and build affinity, timeliness and scientific pragmatism. The practice teaching base expands the scope of students' participation in practice, transforms the school into the campus laboratory of the enterprise, and enables the students' innovative achievements in the practice to serve the enterprise, forming a new mode of coordinated development of production, teaching, research and creation.

2) Practice innovative ability training program. The ability to practice and innovate includes practical hands-on ability, scientific research and innovation ability, and independent research and development ability. Carry out project teaching, case teaching, on-site teaching and situational teaching; organically integrate theory and practice, classroom and laboratory, in-class and extra-curricular, intra-school and offcampus, increase comprehensive practical teaching links, and train students' engineering ability. Invite enterprise technicians to give lectures in stages or concentrate on time by enterprise personnel to jointly conduct quality assessment.

3) School-enterprise cooperation project research. The establishment of campus bases for industry, University and research institutes is a school-enterprise cooperation project. The experimental bases should actively participate in the scientific and technological research of enterprises, help enterprises sort out various technical difficulties in the process of industrial development, establish and actively undertake relevant research topics, and the research results are shared by both sides.

4) Set up an industry-university-research platform. For the core problems and major solutions faced by enterprises and industries, we will build an experimental and practical platform with industry characteristics based on problems. The platform provides students with the opportunity to get in touch with and experience the most cutting-edge technologies, and the full exposure of actual cases will help students discover and develop problem discovery, engineering practice and entrepreneurial abilities.

\section{INDUSTRY-UNIVERSITY-RESEARCH DEEP INTEGRATION} EDUCATION PRACTICE

\section{A. Establishment of Joint Laboratory of Sensing \&Computational Intelligence}

The Department of Computer Science in Beijing Information Science and Technology University was developed from the Department of Computer Software and Computer and Application in the Beijing Institute of Information Engineering founded in 1978. In 2002, the department of computer science and technology was included in the key construction specialty of Beijing universities. In 2008, it was rated as a special construction point of Beijing specialty. In 2009, it was rated as a national-level specialty construction point. The department of Computer Science and Technology is the earliest major focusing on computer software technology and computer application technology. It has trained a large number of technical talents who are active in various industry information leadership positions and has a good social reputation. With the explosive growing of related talents, employers are increasingly demanding the level of talents, which poses a huge challenge to the system of formerly mature training students.

Beijing Globallink Computer Technology Co., Ltd. specializes in the research and development of chess-based artificial intelligence algorithms and the optimization of online game platforms. The company is also the only service provider of China's chess and card integrated business network management project. It has a strong $R \& D$ team of artificial intelligence engines. The company also obtained all the Internet domain commercial development rights of the National Sports General Administration's chess and card sports management center and its regulatory association.

Chess and card game is a kind of puzzle sport that students like to see and hear. Writing intelligent chess and card program is beneficial to the cultivation of computer students' programming ability. In April 2015, Beijing Global link Computer Technology Co., Ltd. and Beijing University of Information Science and Technology signed a strategic cooperation agreement to jointly establish the Sensing \& Computational Intelligence School-Enterprise Cooperation Joint Lab for the cooperation between school and enterprise. Focus on the scientific transformation of scientific research and related achievements in the fields of perception and computational intelligence; aim to achieve scientific and technological innovation through joint research and research; and cultivate innovative talents through the construction of innovative practice bases. The following is an introduction to the work of cultivating innovative talents in experimental bases.

\section{B. Constructing a progressive practice teaching system}

According to the high-level training goal of strong programming ability, strong innovation ability and comprehensive quality, combined with the characteristics of subject and the actual employment situation of graduates, like reference $^{[6]}$, We have constructed the 'four levels and six modules" practical teaching system. The "four levels" refers to the basic knowledge training level, professional knowledge training level, innovation ability training level, engineering ability training level. The "six modules" include basic course 
practice module, specialized course practice module, innovative project training module, innovative competition training module, scientific research project training module and project development module. The four levels and six modules support each other, progress step by step. As shown in graph 2.

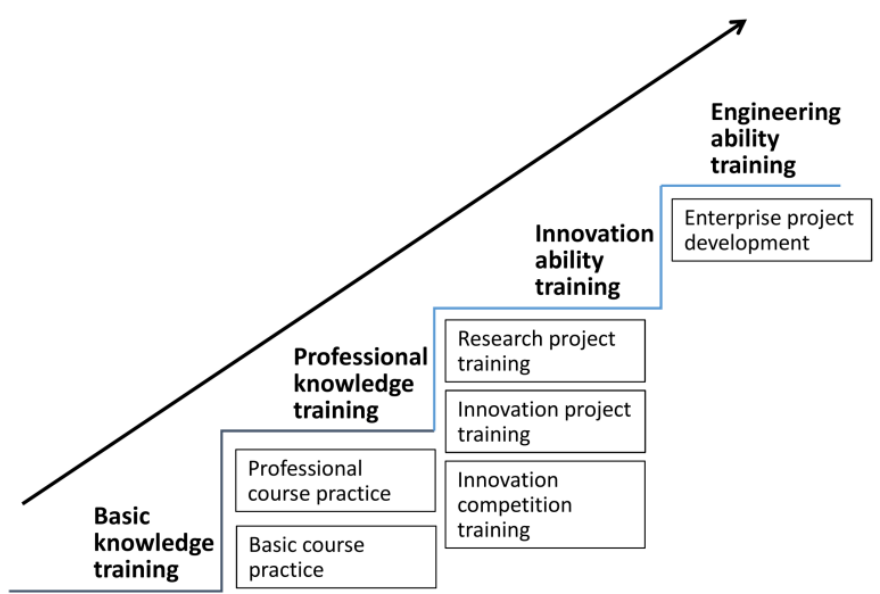

Fig. 2. Progressive Proactive Teaching System

The upgrade from the "basic knowledge training layer" to the "professional knowledge training layer" is mainly implemented by the teaching of basic and professional curriculum. For example, for $\mathrm{C}++$, JAVA programming class of basic course practices module, the design and development of game interface and other topics. For the "Data Structure" and "Algorithm design and analysis" professional course practice module, let students in the realization of the game interface on the basis of the continued development of manmachine combat can be achieved in small programs.

The upgrade from "professional knowledge training layer" to "innovation ability training layer" is mainly through the research of implement innovative projects, innovation competitions and research project training. The innovative project module is mainly aimed at the annual national, municipal and school-level university students' scientific and technological innovation projects which students apply for themselves. The innovation competition module is mainly aimed at more than 20 chess and card competitions such as Liuziqi, Gegeqi, Landlord and Junqi in the China Computer Game Contest ${ }^{[7]}$ held every year. The scientific research project is mainly the research topic of the teacher's own proposition. In the realization of the man-machine battle program technology, the students are instructed to continue the AI algorithm research, and finally realize the computer game program with AI intelligence.

The upgrade from the "innovation ability training layer" to the "engineering ability training layer", the project development module is mainly implemented through a number of research projects signed with the enterprise are used as training content, which greatly enhances the scientific research of students. Ability and engineering practice.

To sum it up, through the practical teaching, the students' innovative application ability and comprehensive quality can be improved in all aspects.

\section{Exploring the Training Plan of Students' Ability with Computer Game as Practical Content}

The ability of discovering problems, analyzing problems, solving problems, self-awareness, organizational coordination, and innovation ability, and cultivating students' ability of scientific research and innovation in all aspects are key ability of talent. We adopt a practice system for all the students from enrollment to graduation. The ability of program design and development is an key aspect of computational thinking ability. In practice, we focus on the training of students' system computer programming ability and design a systematic practical training program, as shown in TABLE I.

TABLE I. St Stent TEACHING PRACTICE BASED ON COMPUTER GAME PROgRAm DESIGN

\begin{tabular}{|c|c|c|c|c|}
\hline Grade & Practice & Course & Experiment/Training & Improve ability \\
\hline $\begin{array}{l}\text { First and second } \\
\text { year of the first } \\
\text { half of the } \\
\text { semester }\end{array}$ & $\begin{array}{c}\text { Basic course } \\
\text { practice module }\end{array}$ & $\begin{array}{l}\mathrm{C}++ \text { / JAVA programming } \\
\text { development practice }\end{array}$ & $\begin{array}{l}\text { Chess interface design and } \\
\text { implementation }\end{array}$ & $\begin{array}{c}\text { Programming ability, program } \\
\text { writing normative }\end{array}$ \\
\hline $\begin{array}{l}\text { Second half of the } \\
\text { second grade or } \\
\text { first half of the } \\
\text { third grade }\end{array}$ & $\begin{array}{l}\text { Professional } \\
\text { course practice } \\
\text { module }\end{array}$ & $\begin{array}{l}\text { Data structure/algorithm design } \\
\text { and analysis }\end{array}$ & $\begin{array}{l}\text { Chess-based computer game system for } \\
\text { everyone }\end{array}$ & $\begin{array}{l}\text { Programming ability, problem } \\
\text { finding, analysis problem, problem } \\
\text { solving, program norm, complete } \\
\text { report of experiment report } \\
\end{array}$ \\
\hline $\begin{array}{l}\text { Second half of the } \\
\text { second grade to the } \\
\text { first half of the } \\
\text { third grade }\end{array}$ & $\begin{array}{l}\text { Innovative } \\
\text { competition } \\
\text { training module }\end{array}$ & $\begin{array}{l}\text { Research project development } \\
\text { practice }(1)\end{array}$ & $\begin{array}{c}\text { Chess-based human-computer game } \\
\text { system }\end{array}$ & $\begin{array}{l}\text { Discover problems, analyze } \\
\text { problems, solve problems, } \\
\text { collaborate, write research reports, } \\
\text { and publish academic papers }\end{array}$ \\
\hline $\begin{array}{l}\text { Second and third } \\
\text { grades of the } \\
\text { second grade }\end{array}$ & $\begin{array}{l}\text { Research project } \\
\text { training module }\end{array}$ & $\begin{array}{c}\text { Research Project Development } \\
\text { Practice (2) / College Students } \\
\text { Science and Technology } \\
\text { Innovation Project } \\
\end{array}$ & $\begin{array}{l}\text { Research on Chess Game System Based } \\
\text { on Deep Learning }\end{array}$ & $\begin{array}{l}\text { Collaboration, research, innovation, } \\
\text { writing research reports and } \\
\text { academic papers }\end{array}$ \\
\hline $\begin{array}{l}\text { Second half of the } \\
\text { second grade to the } \\
\text { first half of the } \\
\text { fourth grade }\end{array}$ & $\begin{array}{l}\text { Innovative } \\
\text { project training } \\
\text { module }\end{array}$ & $\begin{array}{c}\text { Research Project Development } \\
\text { Practice (2) / College Students } \\
\text { Science and Technology } \\
\text { Innovation Project } \\
\end{array}$ & $\begin{array}{l}\text { Research on Chess Game System Based } \\
\text { on AlphaZero }\end{array}$ & $\begin{array}{l}\text { Organizational coordination, } \\
\text { innovation, research capabilities, } \\
\text { writing research reports and } \\
\text { academic papers }\end{array}$ \\
\hline fourth grade & $\begin{array}{l}\text { Engineering } \\
\text { project } \\
\text { development } \\
\text { module } \\
\end{array}$ & $\begin{array}{l}\text { Project development practice / } \\
\text { graduation design }\end{array}$ & $\begin{array}{l}\text { Research on the strategy of playing the } \\
\text { landlord's game, research on the } \\
\text { strategy of guessing the game of } \\
\text { landlords, etc. }\end{array}$ & $\begin{array}{l}\text { Self-awareness, organizational } \\
\text { coordination, innovation ability, } \\
\text { entrepreneurial ability }\end{array}$ \\
\hline
\end{tabular}


Within first month of enrollment, students are encouraged to take part in campus activities to learn about research experiments centers, choose associations, teachers, production according to their interest. The senior students will help them to find problems, analyze problems, solve problems and important programming skills as soon as possible. Teachers mainly guide the normativeness of experimental reports and coding style.

In the second year of the university, the main focus is on the cultivation of students innovation, practice, and scientific research. Students who are interested in the development of the profession or the autonomous laboratory will enter the laboratory and become familiar with the laboratory and some topics and projects under the guidance of the graduate. Teachers encourage students to strengthen the students' practical application consciousness, combine the theoretical knowledge learned in the classroom with the practical ability required by the curriculum design, and guide the practice of theory, and encourage students to study theoretical knowledge seriously from another dimension.

In the third year of the university, the main focus is on the cultivation of students' ability to innovate, practice, collaborate and write academic papers. Guide students to carry out college students' innovation and entrepreneurship training program by enterprise and encourage students to actively participate in various discipline competitions. Through the development of the project, recognize their strengths and weaknesses and better plan future career direction.

In the fourth grade of the university, the main focus is innovation and entrepreneurship education, focusing on the cultivation of students' engineering. Students should participate in the research, application, research and acceptance, and development of the project as much as possible. Introduce students to enterprise production internships and internships, make up for the shortcomings of previous school education and enterprise production, and train students' ability to solve practical problems in production. This kind of edification and practice has a profound influence on the entrepreneurship after graduation, and at the same time, it is beneficial to students to improve their interpersonal skills and other factors, which is conducive to increasing their employment competitiveness.

\section{TEACHING PRACTICE EFFECT}

Since the establishment of the Joint Lab, it has undertaken or completed 2 projects of the National Natural Science Foundation, 1 project of the Education Commission, and 1 open project of the Beijing Key Laboratory. 6 enterprise research projects. We have published more than 30 academic papers, including 1 paper by JCR TOP journal of the Chinese Academy of Sciences, 2 CCF C-class conferences, and more than 10 articles in EI. Four invention patents were filed, of which three were accepted. 14 software copyrights. 10 graduate students will be trained to guide graduate students to complete 3 scientific and technological innovation projects and more than 20 science and technology innovation projects for college students. In the University Computer Games Championship \& National Computer Games Tournament, the students win the champion of the Dots and Boxes Game, the Hex Chess, the Amazon Chess, and the second place of the Dou Di Zhu Game and the EinStein würfelt nicht. The students' innovation ability has been greatly improved, and the cooperation between industry, university and research institute has a good effect.

\section{SUMMARY}

This paper puts forward a campus base construction mode which can serve education and teaching, cultivate students' innovative ability and help to solve the problems encountered in the development of enterprises. It is helpful to form an innovative school-running mode. It has a direct reference value for other colleges and universities, and can also attract more enterprises to participate in University talents. Training to provide successful cases has a strong promotional value.

\section{ACKNOWLEDGMENT}

This work is supported by the special bidding project of teaching \& education reform BISTU (2017JGZB08), the general project of teaching \& education reform BISTU (2017JGYB31; 2017JGYB34).

\section{REFERENCES}

[1] The report of the 19th National Congress of the Communist Party of China: The people won the victory and built a well-off society in an allround way to win the great victory of socialism with Chinese characteristics in the new era. People's Publishing House. 2017.

[2] Heng Chen, Guogang Chu, Jian Hou. Comparative analysis of the cooperation between industry, university and research at home and abroad to cultivate innovative talent models. China Science and Technology Forum. 2018. 1:164-171.

[3] Lixia Zheng, Lei Yan. The model of industry-university-research cooperation project and the research performance of colleges and universities-the intermediary role of R\&D investment. Science and Technology Management Research, 2017, 37 (02): 104-110.

[4] Zhanqi Wang, Yuzhong Qian, Chunshuang Ye. Exploring the mode of training talents in the innovation and entrepreneurship symbiosis schoolenterprise cooperation. Educational theory and practice. 2018, 38 (6): 12-14.

[5] Gui Tong, Yi Zheng. From "school-enterprise cooperation" to "schoolenterprise integration", the application-oriented talent cultivation innovation model. Journal of Nanjing Institute of Technology (Social Science Edition). 2018,18(1):76-80.

[6] Shizhen Zhao, Shuang Wang, Shuang Liu, Zhen Zhang, Jianming Wang, Jianping Niu. Research on the Innovation Model of Industry-UniversityResearch Cooperation--Taking Metal Materials Engineering of Shenyang University as an Example. Journal of Shenyang University (Social Science Edition), 2018, 20(1): 14-17.

[7] China Computer Game Contest Website.http://computergames.caai.cn/ 